\title{
Multifocal Epithelioid Hemangioendothelioma Derived from the Spine Region: Case Report and Literature Review
}

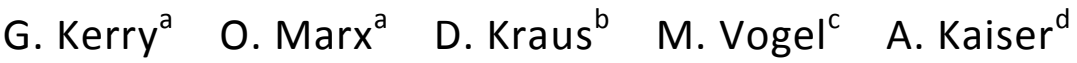 \\ C. Ruedinger $^{a} \quad$ H.H. Steiner ${ }^{a}$ \\ Departments of ${ }^{a}$ Neurosurgery, ${ }^{b}$ General, Visceral and Thoracic Surgery, \\ ${ }^{\mathrm{c}}$ Radiology, and ${ }^{\mathrm{d} P a t h o l o g y, ~ K l i n i k u m ~ N u e r n b e r g, ~ N u r e m b e r g, ~ G e r m a n y ~}$
}

\section{Key Words}

Hemangioendothelioma $\cdot$ Vascular spinal tumor $\cdot$ Bone manifestation $\cdot$ Multifocal metastasis · Interdisciplinarity · Multimodal treatment

\section{Abstract}

Background: Epithelioid hemangioendothelioma (EHE) is a rare vascular tumor with malignant biological behavior. It arises from endothelial cells, usually within soft tissues, and can occur in almost all locations.

Case Report: We report a unique case of a 25 -year-old man who presented with sudden attacks of severe back pain followed by acute non-traumatic paraplegia. Emergency diagnostics revealed a pathologic fracture of the T7 vertebra with tumor tissue invasion of the spinal canal. Furthermore, multifocal metastases were found.

Results: To achieve en bloc resection, interdisciplinary surgical approaches were indicated. Despite multimodal therapy concepts, including radiotherapy and chemotherapy as well as endovascular embolization, the patient died within 8 weeks.

Conclusion: Prognosis of EHE is unpredictable and mainly determined by its location. The lesions are potentially aggressive; therefore, en bloc resection should be attempted whenever possible. However, as shown in the literature, only $15 \%$ of patients are suitable for total resection. 


\section{Introduction}

Epithelioid hemangioendothelioma (EHE) is composed of tumor cells which show endothelial differentiation. It is a rare well-differentiated endothelial tumor with variable presentation and behavior which may develop at different sites, such as in soft tissue, lung, pleura, spleen, heart, liver, as well as intracranial. Primary bone EHE accounts for less than $1 \%$ of malignant bone tumors; cases occurring in the spine region are especially rare. Here, we report a unique case of spinal EHE and present surgical treatments, pathologic findings, and imaging characteristics in a comprehensive review of the literature.

\section{Case Report}

A 25-year-old white male was admitted to our hospital with sudden attacks of severe back pain followed by acute non-traumatic paraplegia. A high-resolution CT scan and MRI of the thoracic spine revealed a pathologic fracture of the T7 vertebral body (VB) with tumor tissue invasion of the spinal canal and a space-occupying epidural hematoma between the T5 and T9 VB (fig. 1). The CT scan of the thorax region also demonstrated numerous pulmonary foci and pleural affections on both sides. Furthermore, lymphonodular and cutaneous metastases were noted.

We conducted emergency surgery and removed the intraspinal tumor masses as well as the spaceoccupying epidural hematoma by extended laminectomy of the T7 VB. The main bulk of the tumor was infiltrating the VB and the paravertebral tissue; it was purple and vascular with a soft consistency. The stabilization of the posterior column was implemented by dorsal instrumentation with internal fixation between the T6 and T8 VB.

Postoperatively, the patient reported considerable clinical improvements; nevertheless, a highgrade bilateral, mainly right-sided, leg paresis as well as urinary bladder dysfunction emerged after $12 \mathrm{~h}$. Early postoperative MRI of the thoracic spine revealed a new space-occupying epidural hematoma between the T5 and T6 VB, so that a right-sided hemilaminectomy of the T5 VB was urgently indicated to achieve a relief of the myelon. After this operation, significant improvements in the form of restored urinary bladder function and a partial restoration of sensory and motor deterioration were achieved. However, after a few days there was once again more unfavorable progress with progressive bilateral leg paresis, so that further operations were conducted to achieve decompression of the spinal canal.

Due to a recurrent secondary hemorrhage, a total spinal tumor resection via transthoracic T7 vertebrectomy with VB replacement by cage interposition was performed. The extirpation of some pleural foci and pulmonary lesions in the left lower lobe was conducted during the same operation via thoracic surgical intervention ( $\underline{\text { fig. } 2}$ ). After this procedure, clinical improvements were achieved, but a considerable amount of blood was lost through the continuous pleural drainage. Due to new deterioration of the clinical status, a transthoracic and dorsal reoperation was done in order to seal the pleural cavity.

A histological examination, including immunohistochemical profile, confirmed the endothelial and vascular nature of the lesion with both the intervening as well as vascular space-lining cells showing positivity for the endothelial cell markers CD31, MIB-1, and factor VIII-related antigen. The diagnosis of infiltrating epithelioid hemangioendothelioma was made. The histological profile of the pulmonary and pleural lesions was identical to that of the VB ( $\underline{\text { fig. } 3}$ ).

Afterwards, a stable neurological status was achieved; however, the origin of the hemorrhage was indiscernible and a considerable amount of blood was still being lost through the pleural drainage. All coagulation parameters were within normal range over the entire treatment period, and multiple blood transfusions were used to temporarily compensate for the lack of blood cells.

The ensuing limited-field radiotherapy (RT) and chemotherapy with doxorubicin as well as endovascular embolization of tumor-supplying intercostal arteries could not stop the recurrent 
secondary hemorrhage. Despite interdisciplinary surgical management and multimodal therapy concepts, the patient died within 8 weeks due to uncontrolled intrathoracic bleeding.

\section{Discussion}

EHE has had several varying labels such as histiocytoid hemangioma, cellular hemangioma, low-grade anaplastic angiosarcoma, and angioendothelioma. The term EHE was designed to describe tumors that had an appearance between infantile hemangiomas and sarcomas. The highest incidence of the disease occurs during the second and third decades. Males and females are affected approximately equally. Cytogenetic research has shown inconsistent results, including the translocations $\mathrm{t}(1 ; 3)(\mathrm{p} 36.3 ; \mathrm{q} 25)$ and $\mathrm{t}(10 ; 14)(\mathrm{p} 13 ; \mathrm{q} 42)$, and gains and deletions involving chromosomes 11 and 12 [1].

EHE typically presents with non-specific signs and symptoms, most commonly painful lesions which may be associated with a mass, thereby resulting in a loss of function. Vascular or neurological symptoms appear depending on the location. The typical radiographic and CT appearance of EHE arising in bone is a lytic lesion without matrix mineralization; osseous expansile remodeling may be seen. Joint invasion is a common feature and homogeneous enhancement is present on contrast materialenhanced CT or MRI. The signal intensity characteristics on MR images are non-specific. There is low-to-intermediate signal intensity on $\mathrm{T}_{1}$-weighted images and high signal intensity on $\mathrm{T}_{2}$-weighted images. The aggressive radiographic appearance of EHE raises the suspicion of malignancy. Differential considerations for this radiographic presentation include Langerhans' cell histiocytosis, giant cell tumors, fibrous dysplasia, lymphoma, and metastatic diseases [2].

Histopathological evaluation is central to the diagnosis of this tumor. At pathological analysis, the tumor may be well circumscribed or have indistinct borders. The surface is macroscopically light red or purple, with a soft consistency associated with bone fragments. The distinct well-lined anastomosing vascular channels often seen in hemangiopericytoma are absent in this tumor. Cells may be round or fusiform with a central nucleus and prominent intracytoplasmic vacuolation. The positivity of endothelial cell markers CD31 and factor VIII-related antigen is essential in the diagnosis, as in the specimen in our case. Classification of malignant potential relies on the degree of vasoformative activity, atypia of the endothelial cells, and the frequency of mitotic activity as predictive signs. Unlike other aggressive vascular tumors, such as hemangioendothelial sarcoma or angiosarcoma, the histological grading system is not useful for predicting prognosis [1-3].

Treatment options and prognosis of spinal EHE are sources of controversy, not least because of the small number of patients and the short follow-up periods. We present the clinical course and treatment of spinal EHE as documented in the few cases in the literature (table 1).

The 19 cases of EHE were located in the spine region: 5 of them in the cervical, 8 in the thoracic and 3 in the lumbar spine region, 1 in the cervical and thoracic spine regions, 1 in the thoracic and lumbar spine regions and 1 in all three regions. Eighteen 
lesions involved the VB and only 1 lesion was intradural with intramedullary extension without bone infiltration.

The main symptom was local pain in 15 cases; pathological fractures were observed in 5 patients and perioperative embolization was attempted in 2 cases. Of the 19 cases, 17 patients underwent surgical intervention. In 3 of those cases, an in sano resection was possible and no RT or chemotherapy was needed. The follow-up periods were between 8 months and 4 years, and the patients were clinically asymptomatic without signs of recurrent or metastatic disease. Fourteen patients underwent subtotal resection: 6 cases with adjuvant RT alone, 1 case with adjuvant chemotherapy alone, 2 cases with combined adjuvant RT and chemotherapy, 1 case with combined adjuvant steroid therapy and RT, and 4 cases without any adjuvant therapy.

There was no tumor recurrence in 3 cases after subtotal resection and adjuvant RT within follow-up periods between 6 months and 4 years; there was also no tumor recurrence in the 2 cases of subtotal tumor resection and combined adjuvant RT and chemotherapy within follow-up periods between 6 months and 11 years.

In one case, during a follow-up period of 20 months, the patient remained neurologically asymptomatic, but abdominal wall metastases appeared despite subtotal tumor resection and adjuvant RT. The patient who underwent subtotal tumor resection and combined adjuvant steroid therapy and RT was clinically asymptomatic in a followup period of 1 month. In 2 cases, no surgical treatment was attempted; in 1 of these 2 cases, combined RT and chemotherapy were given and the patient was neurologically asymptomatic during a follow-up period of 20 months. In the other case, no further therapy was mentioned and the case outcome was not stated.

Death occurred in 5 cases in total: 3 patients, including our presently reported case, died during the treatment course; the other 2 patients died due to liver and lung metastases after 20 months in 1 case, and 5 years in the other. In all 5 of these cases, an in sano resection was not possible.

\section{Conclusion}

EHE involving the spine region is extremely rare. The key to diagnosis is the immunohistochemical evidence of endothelial differentiation. In questionable cases, it is essential to use multiple vascular markers. The histological features of the tumor are of no value in predicting clinical outcome. It has been suggested that EHE of soft tissue is better regarded as a fully malignant, rather than borderline, vascular neoplasm; albeit the prognosis is better than in conventional angiosarcoma. Furthermore, it is important to survey not only the skeleton but also the visceral organs to determine the full extent of the disease in these patients. In our case, the poor prognosis was associated with recurrent secondary hemorrhages and uncontrolled intrathoracic bleeding.

Because of the relatively minor number of reported cases and the short follow-up periods, the ideal treatment of these tumors is not entirely clear. Nevertheless, our experience through this case and the observations of others suggest that en bloc resection is the treatment of choice for spinal EHE; it significantly lengthens the time 
until local recurrence and is to be attempted whenever possible. However, as shown in the literature, in series of primary and metastatic spinal EHE, only $15 \%$ of patients are suitable for total resection.

The authors of recent publications suggest radiation as an adjuvant treatment in cases of residual tumor. Although chemotherapy and immunotherapy have been used as adjuvant treatments, their role has not been clearly defined.

\section{Disclosure Statement}

The authors declare that there is no conflict of interest. 
Table 1. Clinical details of documented cases of spinal EHE

\begin{tabular}{|c|c|c|c|c|c|}
\hline $\begin{array}{l}\text { Year of publication, } \\
\text { authors }\end{array}$ & $\begin{array}{l}\text { Age years, } \\
\text { gender }\end{array}$ & $\begin{array}{l}\text { Presenting } \\
\text { symptoms }\end{array}$ & Localization & Management & $\begin{array}{l}\text { Follow-up period, } \\
\text { outcome }\end{array}$ \\
\hline $\begin{array}{l}2011, \\
\text { our present case }\end{array}$ & $25, \mathrm{M}$ & $\begin{array}{l}\text { back pain, acute } \\
\text { paraplegia }\end{array}$ & $\begin{array}{l}\text { T7 VB; pulmonary, } \\
\text { pleural, lymphonodular } \\
\text { and cutaneous } \\
\text { metastases }\end{array}$ & $\begin{array}{l}\text { T7 vertebrectomy decompression, } \\
\text { stabilization, resection of pulmonary } \\
\text { metastases, embolization, RT and } \\
\text { chemotherapy }\end{array}$ & $\begin{array}{l}\text { died within } 8 \text { weeks } \\
\text { due to uncontrolled } \\
\text { intrathoracic } \\
\text { bleeding }\end{array}$ \\
\hline $\begin{array}{l}2010, \\
\text { Neves et al. [14] }\end{array}$ & $51, \mathrm{~F}$ & $\begin{array}{l}\text { lower back pain, } \\
\text { progressive } \\
\text { paraplegia }\end{array}$ & L1 VB & $\begin{array}{l}\text { L1 corpectomy, vertebral spacer, } \\
\text { lateral plate fixation, T10-L4 pedicle } \\
\text { instrumentation and fusion }\end{array}$ & $\begin{array}{l}6 \text { years, } \\
\text { asymptomatic }\end{array}$ \\
\hline $\begin{array}{l}\text { 2006, } \\
\text { Gokhan et al. [12] }\end{array}$ & $30, \mathrm{M}$ & $\begin{array}{l}\text { lower back pain, } \\
\text { urinary incontinence, } \\
\text { numbness, difficulty } \\
\text { in walking }\end{array}$ & L1 and L2 VB & $\begin{array}{l}\text { L1 vertebrectomy, total tumor } \\
\text { resection, T12-L2 interbody fusion, } \\
\text { T12-L3 stabilization }\end{array}$ & $\begin{array}{l}8 \text { months, } \\
\text { no major complaint }\end{array}$ \\
\hline $\begin{array}{l}2005, \\
\text { Abuzallouf et al. [3] }\end{array}$ & $41, \mathrm{M}$ & $\begin{array}{l}\text { lower back pain, } \\
\text { urinary retention, } \\
\text { numbness }\end{array}$ & $\begin{array}{l}\text { spinal intradural tumor } \\
\text { at the level of } \mathrm{T} 12\end{array}$ & tumor resection, RT & $\begin{array}{l}4 \text { years, } \\
\text { no tumor recurrence }\end{array}$ \\
\hline $\begin{array}{l}2005, \\
\text { Adler et al. [2] }\end{array}$ & $16, \mathrm{M}$ & $\begin{array}{l}\text { syncopal episodes } \\
\text { and cephalgia }\end{array}$ & $\begin{array}{l}\text { cervical spine, skull } \\
\text { base, skeleton, lungs, } \\
\text { liver, kidneys }\end{array}$ & subtotal excisions & $\begin{array}{l}\text { died during the } \\
\text { treatment course }\end{array}$ \\
\hline $\begin{array}{l}\text { 2005, } \\
\text { Aquilina et al. [5] }\end{array}$ & $17, \mathrm{M}$ & lower back pain & T10 VB & $\begin{array}{l}\text { T10 vertebrectomy, iliac crest strut } \\
\text { graft, stainless steel plate, extensive } \\
\text { resection of the tumor, RT and } \\
\text { chemotherapy }\end{array}$ & $\begin{array}{l}11 \text { years, } \\
\text { asymptomatic }\end{array}$ \\
\hline $\begin{array}{l}\text { 2005, } \\
\text { Aquilina et al. [5] }\end{array}$ & $60, \mathrm{M}$ & $\begin{array}{l}\text { neck pain, } \\
\text { progressive flexion } \\
\text { deformity }\end{array}$ & $\mathrm{C} 2, \mathrm{C} 3$, and $\mathrm{C} 4 \mathrm{VB}$ & $\begin{array}{l}\text { posterior occipitocervical } \\
\text { stabilization, RT }\end{array}$ & $\begin{array}{l}\text { died after } 20 \text { months } \\
\text { of hepatic metastases }\end{array}$ \\
\hline $\begin{array}{l}2004, \\
\text { Casey et al. [8] }\end{array}$ & $60, \mathrm{M}$ & $\begin{array}{l}\text { neck pain, fixed neck } \\
\text { flexion }\end{array}$ & $\mathrm{C} 2, \mathrm{C} 3$ and $\mathrm{C} 4 \mathrm{VB}$ & $\begin{array}{l}\text { posterior occipitocervical } \\
\text { stabilization, RT }\end{array}$ & $\begin{array}{l}2 \text { years, } \\
\text { asymptomatic }\end{array}$ \\
\hline $\begin{array}{l}\text { 2003, } \\
\text { Evans et al. [1] }\end{array}$ & $25, \mathrm{M}$ & lower back pain & $\begin{array}{l}\text { T11 VB, skull and left } \\
\text { femur }\end{array}$ & stabilization and chemotherapy & $\begin{array}{l}5 \text { years, } \\
\text { died due to liver and } \\
\text { lung metastases } \\
\end{array}$ \\
\hline $\begin{array}{l}\text { 2001, } \\
\text { Brennan et al. [7] }\end{array}$ & $28, \mathrm{M}$ & $\begin{array}{l}\text { numbness of both } \\
\text { legs, weakness, } \\
\text { unbalanced gait }\end{array}$ & $\begin{array}{l}\text { C5, C6 VB and C7 } \\
\text { vertebral transverse } \\
\text { process }\end{array}$ & $\begin{array}{l}\text { embolization, fusion and } \\
\text { decompression, RT }\end{array}$ & $\begin{array}{l}6 \text { months, } \\
\text { decreased } \\
\text { complaints }\end{array}$ \\
\hline $\begin{array}{l}\text { 2001, } \\
\text { Faust et al. [11] }\end{array}$ & $58, \mathrm{~F}$ & $\begin{array}{l}\text { segmental sensory } \\
\text { disturbance, } \\
\text { Horner's syndrome }\end{array}$ & C7-T4 VB & subtotal tumor excision & died within 4 weeks \\
\hline $\begin{array}{l}\text { 2001, } \\
\text { Chau et al. [9] }\end{array}$ & $17, \mathrm{~F}$ & $\begin{array}{l}\text { left-sided weakness, } \\
\text { cephalgia }\end{array}$ & $\begin{array}{l}\text { lateral mass of C1 } \\
\text { vertebra, left occipital } \\
\text { condyle }\end{array}$ & suboccipital craniectomy & $\begin{array}{l}\text { case outcome not } \\
\text { stated }\end{array}$ \\
\hline $\begin{array}{l}\text { 1996, } \\
\text { Boutin et al. [6] }\end{array}$ & $24, \mathrm{M}$ & $\begin{array}{l}\text { neck stiffness and } \\
\text { back pain }\end{array}$ & $\begin{array}{l}\text { multiple lesions } \\
\text { (cervical, thoracic and } \\
\text { lumbar), } 45 \text { bones }\end{array}$ & chemoradiotherapy & $\begin{array}{l}20 \text { months, } \\
\text { neurologically } \\
\text { asymptomatic }\end{array}$ \\
\hline $\begin{array}{l}\text { 1996, } \\
\text { Ellis et al. [10] }\end{array}$ & $31, \mathrm{~F}$ & lower back pain & L2 VB & $\begin{array}{l}\text { L2 vertebrectomy, strut grafting, } \\
\text { excision of the L1-L2 and L2-L3 } \\
\text { intervertebral discs }\end{array}$ & $\begin{array}{l}18 \text { months, } \\
\text { neurologically } \\
\text { asymptomatic }\end{array}$ \\
\hline $\begin{array}{l}\text { 1992, } \\
\text { Abrahams et al. [4] }\end{array}$ & $34, \mathrm{M}$ & $\begin{array}{l}\text { back pain and leg } \\
\text { numbness }\end{array}$ & T3 VB & $\begin{array}{l}\text { biopsy; further therapy was not } \\
\text { mentioned }\end{array}$ & $\begin{array}{l}\text { case outcome not } \\
\text { stated }\end{array}$ \\
\hline $\begin{array}{l}\text { 1986, } \\
\text { Tsuneyoshi et al. [15] }\end{array}$ & $73, \mathrm{M}$ & pain & $\begin{array}{l}\mathrm{T} 10, \mathrm{~T} 12 \text {, and } \mathrm{L} 1 \\
\text { vertebrae }\end{array}$ & curettage and RT & $\begin{array}{l}\text { case outcome not } \\
\text { stated }\end{array}$ \\
\hline $\begin{array}{l}\text { 1986, } \\
\text { Tsuneyoshi et al. [15] }\end{array}$ & $16, \mathrm{M}$ & pain & T9 VB & curettage & $\begin{array}{l}4 \text { years, } \\
\text { asymptomatic }\end{array}$ \\
\hline $\begin{array}{l}\text { 1986, } \\
\text { Tsuneyoshi et al. [15] }\end{array}$ & $26, \mathrm{M}$ & pain & T11 VB & tumor resection and RT & $\begin{array}{l}20 \text { months, } \\
\text { asymptomatic, } \\
\text { abdominal wall } \\
\text { metastases }\end{array}$ \\
\hline $\begin{array}{l}\text { 1985, } \\
\text { Maruyama et al. [13] }\end{array}$ & $43, \mathrm{~F}$ & $\begin{array}{l}\text { pain and cord } \\
\text { compression }\end{array}$ & $\begin{array}{l}\text { T3 VB and multicentric } \\
\text { bone involvement } \\
\text { outside the spine }\end{array}$ & $\begin{array}{l}\text { tumor resection, steroid therapy } \\
\text { and RT }\end{array}$ & $\begin{array}{l}1 \text { month, } \\
\text { asymptomatic }\end{array}$ \\
\hline
\end{tabular}




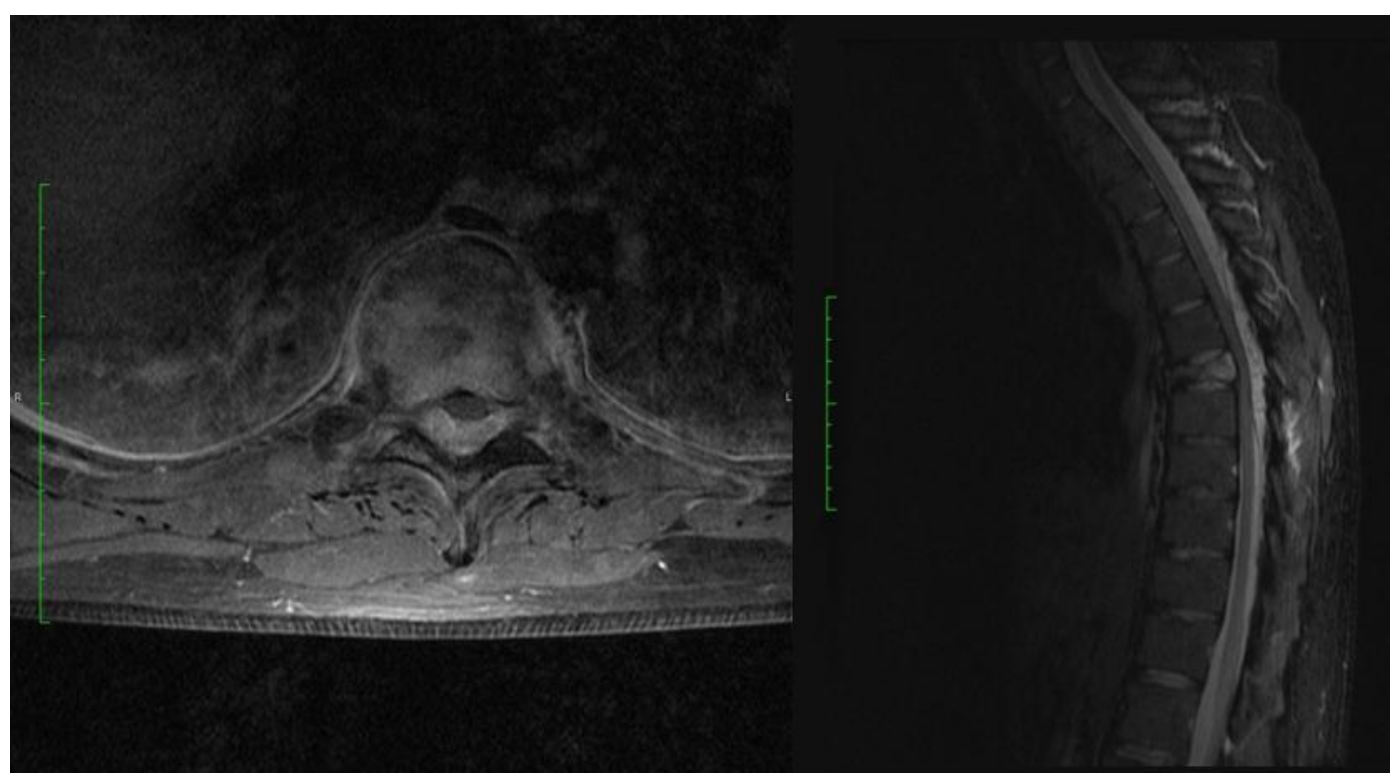

Fig. 1. T1-weighted axial MR image after contrast administration (left) and sagittal STIR MR image (right) showing the lesion.

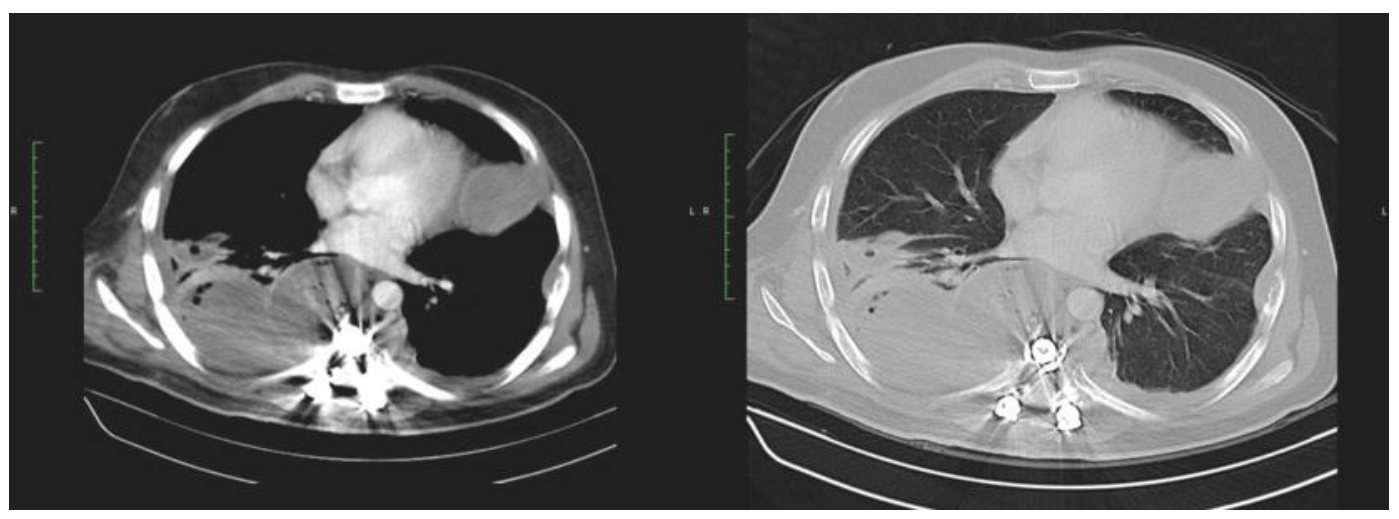

Fig. 2. CT scan after extirpation of pleural foci and pulmonary lesions in the left lower lobe. 


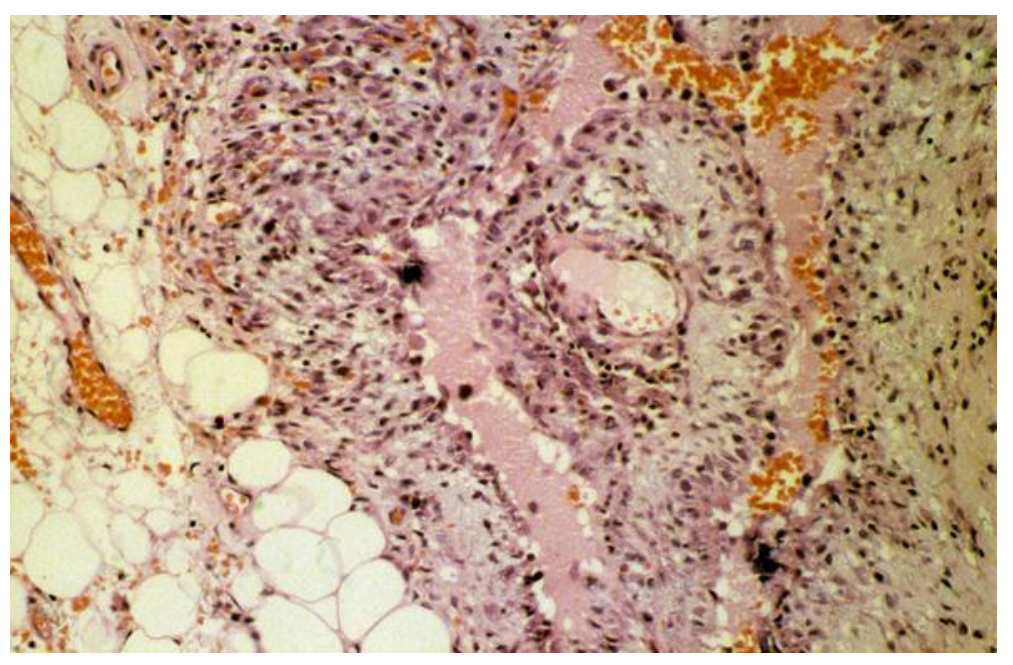

Fig. 3. Pleomorphic neoplastic cells are seen in the center of the picture (Hematoxylin and Eosin stain, original magnification $\times 200$ ).

\section{References}

$\checkmark 1$ Evans HL, Raymond AK, Ayala AG: Vascular tumors of bone: a study of 17 cases other than ordinary hemangioma, with an evaluation of the relationship of hemangioendothelioma of bone to epithelioid hemangioma, epithelioid hemangioendothelioma and high grade angiosarcoma. Hum Pathol 2003;34:680-689.

-2 Adler B, Naheedy J, Yeager N, Nicol K, Klamar J: Multifocal epithelioid hemangioendothelioma in a 16year-old boy. Pediatr Radiol 2005;35:1014-1018.

3 Abuzallouf S, Wong R, Mintz AP, Provias J: Hemangioendothelioma of the spinal cord with intramedullary extension. Med Princ Pract 2005;14:354-357.

4 Abrahams T, Bula W, Jones M: Epithelioid hemangioendothelioma of bone. A report of two cases and review of the literature. Skeletal Radiol 1992;21:509-513.

5 Aquilina K, Lim C, Kamel MH, Marks CJ, O’Sullivan MG, Keohane C: Epithelioid hemangioendothelioma of bone. J Neurosurg Spine 2005;3:393-399.

-6 Boutin RD, Spaeth HJ, Mangalik A, Sell JJ: Epithelioid hemangioendothelioma of bone. Skeletal Radiol 1996;25:391-395.

-7 Brennan JW, Midha R, Ang LC, Perez-Ordonez B: Epithelioid hemangioendothelioma of spine presenting as cervical myelopathy: case report. Neurosurgery 2001;48:1166-1169.

>8 Casey MC, Lim C, Hickey MC: An unusual cause of neck pain. Br J Radiol 2004;77:539-540.

9 Chau YP, Chan ACL, Wong CC: Lytic lesion in a vertebra of a 17-year-old adolescent girl. Arch Pathol Lab Med 2001;125:1611S-1612S.

10 Ellis TS, Schwartz A, Starr JK, Riedel CJ: Epithelioid hemangioendothelioma of the lumbar vertebral column: case report and review of literature. Neurosurgery 1996;38:402-407.

11 Faust J, Schmidt M, Ezsel P, Wanitschke R: Epithelioid hemangioendothelioma of the spine (in German). Med Klin 2001;96:740-744.

12 Gokhan GA, Akyuz M, Gurer IE, Tuncer R: Epithelioid hemangioendothelioma derived from the spine region: case report and review of literature. Wien Klin Wochenschr 2006;118:358-361.

13 Maruyama N, Kumagai Y, Ishida Y, Sato H, Sugano I, Nagao K: Epithelioid hemangioendothelioma of the bone tissue. Virchows Arch A Pathol Anat Histopathol 1985;407:159-165.

14 Neves N, Lima-Rodrigues F, Ribeiro-Silva M, Cacho-Rodrigues P, Eloy C, Paiva ME, Pinto R: Epithelioid hemangioendothelioma presenting as a vertebral fracture. Acta Reumatol Port 2010;35:370-374.

15 Tsuneyoshi M, Dorfman HD, Bauer TW: Epithelioid hemangioendothelioma of bone. A clinicopathologic, ultrastructural, and immunohistochemical study. Am J Surg Pathol 1986;10:754-764. 